\title{
THE ANALYSIS OF MACROECONOMIC DETERMINANTS OF THE BANKING SECTOR LIQUIDITY WITH ROLE IN FINANCING AGRICULTURAL SECTOR
}

\author{
Dragana Milićc ${ }^{1}$ Dragan Soleša ${ }^{2}$
}

\begin{abstract}
Summary
In this study, we aimed to identify the factors of the greatest impact on the banking sector liquidity in order to support agricultural business. The main goal of the research is based on the assessment of whether and how the variation of macroeconomic factors affect the exposure of the banking sector to liquidity risk, which is determined by the willingness of the banking sector to respond to the growing financial needs of agriculture. By using the appropriate statistical methods such as correlation and multiple regression analysis, we obtained significant results that can form the basis for monitoring and measuring il/liquidity of the banking sector in relation to the real agricultural sector. The obtained results confirm inflation and unemployment rates as determinants of liquidity in the banking sector. More importantly, this can help to plan, i.e. predict the funds for agricultural sector.
\end{abstract}

Key words: macroeconomic factors, the banking sector liquidity, statistical methods, agricultural development.

JEL: G21, E02, Q14.

\section{Introduction}

Liquidity represents the ability of banks to provide liquid funds for payment of due and withdrawn deposits in order to fund asset growth and business operations, as well as to settle other foreseen and unforeseen financial obligations. Since the illiquidity of a bank has significant consequences on its operations and business clients who invested funds in the bank as well as those who use loans and a variety of services, the need for a bank to be highly liquid is nothing special and new, but something normal and usual and as Cates states "Liquidity is always primary, without liquidity the bank does not open its door. But with liquidity, the bank may have time to solve the biggest problem" (Cates, 1990). Liquidity risk (Klincov et

1 Dragana Milić, Teaching Assistant, Novi Sad Business School, Vladimira Perića Valtera street no. 4, 21000 Novi Sad, Serbia, Phone: +381 214854 000, E-mail: draganaim84@gmail.com.

2 Soleša Dragan Ph.D., Full Professor, Economic Academy University, Faculty for Economy and Engineering Management, Cvećarska street no. 2, 21000 Novi Sad, Phone: +381 21 400 484, E-mail: solesadragan@gmail.com.

EP 2017 (64) 2 (533-550) 
al., 2017) is the risk of insufficient liquid funds available for these needs at a given time, and it also contains an aspect of market risk with respect to bank's inability to carry out transactions in the financial market due to systemic disorders in the country or due to insufficient market depth. The liquidity issue is presented as the deficit in reserves or hindered or impossible acquisition of liquid assets at a reasonable market price.

Banks that ensure greater liquidity before the crisis will be able to act as a liquidity service for customers who do not have established credit lines. On the other hand, foreign banks which are facing liquidity pressures will cause expansion of the sale of assets at low prices on their markets. In times of crisis, banks with excess liquidity are able to develop new business and take over the affairs of other banks by buying their assets at low prices. An example of this can be found in the book of City bank 1812 - 1970, in which authors explain how the central bank - City bank used its high liquidity strategy before the crisis, both in 1893 and 1907, and how this strategy has led to an increase in new loans and deposits. This indicates that the bank was able to increase its role as liquidity provider and maintain its liquidity risk constant. During the recent financial crisis, somewhat opposite trend appeared. Banks, even though they enjoy excess liquidity, are not willing to act as liquidity creators. The uncertainty that stems from the fear of the future liquidity is the reason why banks are hesitant to lend to other banks in times of crisis.

The structure of this paper is divided in four parts. The introductory part of the paper explains the importance of bank liquidity, i.e. both the banking sector liquidity and research problems are defined. The second part relates to the review of the literature and researchers who have also explored this topic. The third part of the paper explains the methodology and presents the data used for the purpose of determining factors which have the greatest impact on the banking sector liquidity. The last part of the paper analyzes the study results that will help to draw the conclusions and highlight new insights for further research.

\section{Review of literature}

Numerous authors have studied the banks liquidity, i.e. changes in the liquidity level due to the effect of different factors. Some of them are: Trenca, Petria, Mutu \& Corovei, Vodová, Basel Committee on Banking Supervision Working Group on Liquidity, Alihodžić, Račić and others. The conclusions they came to relate to the identification of relevant and significant macroeconomic factors which affect the liquidity level in the banking sector.

For example, in his study, Račić (2014) identifies the factors influencing the liquidity of banks in the period from 2008-2012. The study results support the idea that the movement of the underlying macroeconomic factors contributed to the high liquidity of the banking sector in Serbia. The increase in the unemployment rate, inflation rate, determine the exposure of the banking sector to liquidity risk at a statistically significant level. Also, in his study, the correlation between the banking sector liquidity and phases of the business cycle are examined.

Through a multiple regression analysis model in his study, Alihodžić (2015) establishes whether there is a mutual causality and performance-based conditionality of the real and 
banking sectors for the period from Q4 2008 to Q4 2014. As a dependent variable, he uses the gross domestic product, and as independent variables: total number of loans for the private sector, the referential interest rate, savings, inflation, export and imports of goods and services. Generally, there was a positive correlation with all variables except the inflation, and a partly weak correlation between the referential interest rate and the gross domestic product.

Vodová (2011), in his study, identifies determinants of liquidity of Slovakian commercial banks in the period from 2001 to 2010 using the panel regression model. The paper states that banks liquidity generally declines during the crisis, so the liquid assets reduce with higher profitability of banks and higher capital adequacy reduces in case of larger banks. Bank liquidity, measured through the credit activity, increases with the growth of gross domestic product and decreases with rising unemployment, while the interest rate, the interest margin, inflation and non profitable loans have no statistically significant impact on the liquidity of Slovakian commercial banks.

\section{Methodology and data}

The aim of this study is based on the assessment whether and how the variation of macroeconomic factors affected the exposure of the banking sector to liquidity risk in the period from 2008 to 2015.

The importance of the banking sector liquidity for the development of the financial market in Serbia, and therefore the economy, encouraged the study of this very topic. Namely, authors investigated which macroeconomic determinant has the highest dependency in relation to the dependent variable (the banking sector liquidity). It also emphasizes the importance and great potential of statistical methods such as descriptive statistics, correlation and a multiple regression analysis in measuring the individual and combined effects of the variables on the dependent variable. The study results confirm the importance of the inflation rate, unemployment rate and gross domestic product as indirect determinants of banking sector liquidity. This study is expected to have the practical use for economic policy makers in monitoring and measuring precisely the most influential factors on banking sector liquidity and the possibility of timely response to the given movements.

Thus, the focus of the study is based on the following tasks:

1. Implementing descriptive data analysis;

2. Determining the existence of links between macroeconomic variables and banking sector liquidity;

3. Establishing a model to measure the contribution of independent variables to the variance of the dependent variable.

The study covers the period from 2008 to 2015 and refers to the liquidity of the banking sector. The authors mainly used official data of the National Bank of Serbia. We included three independent variables, the gross domestic product (GDP) - reported by the index of industrial production (IIP), inflation (CPI), the unemployment rate (UNIP) and one dependent variable 
which was expressed through two indicators (liquid assets/liquid liabilities, loans/deposits). Accordingly, we applied correlation and a multiple regression analysis of 96 observations using the statistical program SPSS.

Null and alternative hypotheses can be defined based on the research of many authors on this and similar topics.

H0: Macroeconomic factors did not affect the exposure of the banking sector to liquidity risk in the period from 2008 to 2015 .

H1: The macroeconomic factors affected the banking sector exposure to liquidity risk in the period from 2008 to 2015 .

\section{Study results and discussion}

Application of descriptive method made it possible to describe the variables that were the subject of research. This method also involved reducing the amount of data obtained in the study to a small number of measures and their presentation in an appropriate form, i.e. a statistically acceptable manner. Table below shows the descriptive statistics of macroeconomic variables and the liquidity of the banking sector for the period from 2008 to 2015.

Descriptive statistics of the sample covered by the study is shown in Table 1. It can be noticed that there is a high degree of variation of observed indicators, as evidenced by the standard deviation. The most noticeable is the loans-to-deposit ration to non-financial sector of $11.88 \%$ and the index of industrial production of $9.6 \%$. In Skewness column, we see that CPI values deviate mostly from the normal distribution with the curvature to the left, that is, to smaller values than the average. Liquidity (averLiq) also shows the positive value of curvature, while the other three parameters are curved to the right, i.e. to higher values. Parameter Kurtosis is a measure of the distribution curve flattening. Negative values of this parameter were recorded in all variables and show that the distribution is flatter than normal, i.e. that the data dispersion is bigger. Skewness value of -1 to 1 indicate a normal distribution. Kurtosis values greater than 3 and less than -3 indicate a deviation from the normal distribution.

Table 1. Descriptive statistics of macroeconomic variables and the liquidity of the banking sector of the Republic of Serbia for the period 2008-2015.

\begin{tabular}{|c|c|c|c|c|c|c|c|c|c|}
\hline & $\mathbf{N}$ & Min & Max & Mean & SD & \multicolumn{2}{|c|}{ Skewness } & \multicolumn{2}{c|}{ Kurtosis } \\
\cline { 2 - 10 } & & & & & & Stat & SE & Stat & SE \\
\hline UNIP & 96 & 26.5 & 31.9 & 29.500 & 1.4173 & -.286 & .246 & -.883 & .488 \\
\hline CPI & 96 & -1.0 & 14.7 & 4.023 & 4.4334 & 1.075 & .246 & -.355 & .488 \\
\hline IIP & 95 & 74.5 & 120.5 & 99.866 & 9.6042 & -.291 & .247 & -.208 & .490 \\
\hline averLiq & 96 & 1.50 & 2.68 & 2.1072 & .27232 & .179 & .246 & -.264 & .488 \\
\hline LTD & 96 & 94.00 & 133.60 & 113.8875 & 11.88108 & -.049 & .246 & -1.490 & .488 \\
\hline
\end{tabular}

Source: Author

To further verify whether the distribution of data deviate significantly from the normal distribution, following tests of distribution normality were conducted: Kolmogorov-Smirnov 
and Shapiro-Wilk. In this case, we observe the Kolmogorov test because the sample is greater than 50 observations. The values in the column Sig show that only the distribution of values IIP does not deviate significantly from the normal distribution ( $\mathrm{p}>0.05)$, while deviation from the normal distribution is noticeable for other variables.

Table 2. Tests of Normality

\begin{tabular}{|l|c|c|c|c|c|c|}
\hline \multirow{2}{*}{ UNIP } & \multicolumn{3}{|c|}{ Kolmogorov-Smirnov $^{\mathbf{a}}$} & \multicolumn{3}{c|}{ Shapiro-Wilk } \\
\cline { 2 - 7 } & Statistic & $\mathrm{df}$ & Sig. & Statistic & df & Sig. \\
\hline CPI & .100 & 96 & .019 & .963 & 96 & .009 \\
\hline IIP & .268 & 96 & .000 & .794 & 96 & .000 \\
\hline averLiq & .078 & 95 & .191 & .988 & 95 & .526 \\
\hline LTD & .107 & 96 & .009 & .969 & 96 & .021 \\
\hline
\end{tabular}

\section{a. Lilliefors Significance Correction}

Source: Work of authors

Based on the histogram of dependent and independent variables we can conclude that the independent variables: index of industrial production, unemployment rate, as well as the dependent variables: average monthly liquidity ratio and loans-to-deposit ratio to nonfinancial sector (LTD) does not deviate significantly from the normal distribution, while the distribution of the consumer price index (CPI) is asymmetric i.e. curved toward lower values.

Figure 1. Histogram of dependent and independent variables

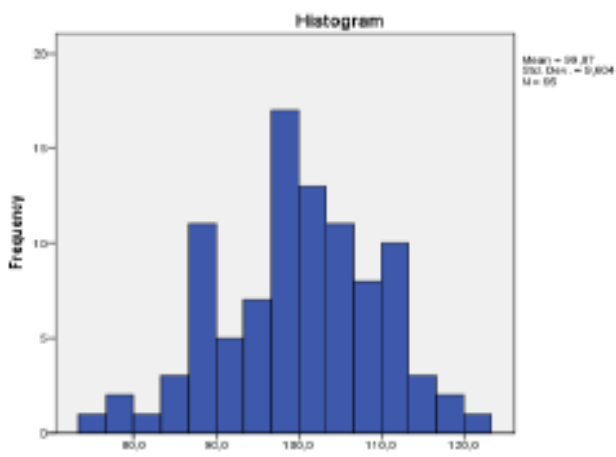

Index of industrial production

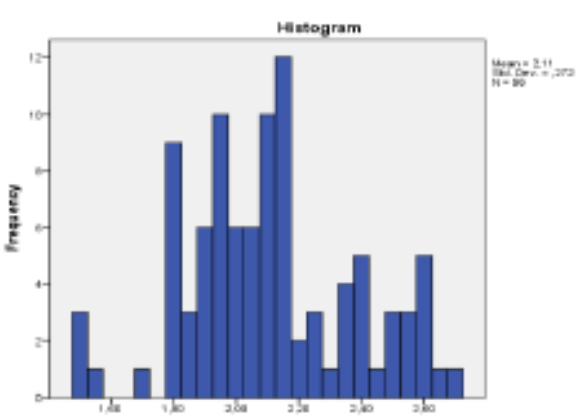

Average monthly liquidity ratio 


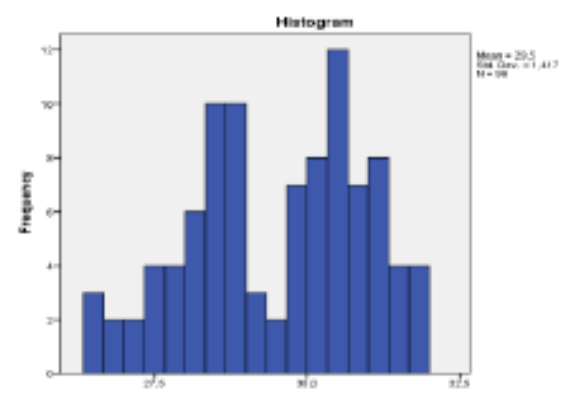

Unemployment rate

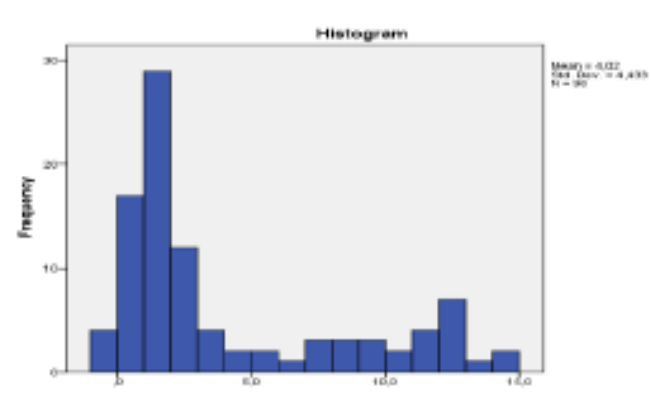

Inflation

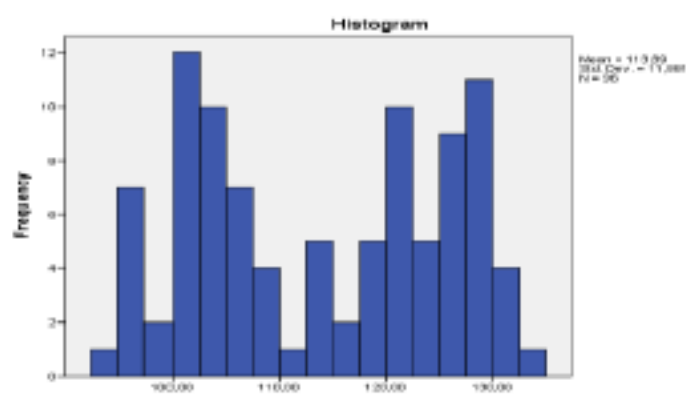

Loans-to-deposits ratio

Source: Work of authors

Normal Probability Plot (P-P) of the Regression Standardised Residual as well as the diagram of dispersion, show that prerequisites of normal distribution of data are not disturbed to a large extent. In the Normal Probability Plot (P-P) diagram, we see that the relationship is linear and does not deviate significantly from the straight line - which means that it does not deviate significantly from the normal distribution. Scatterplot diagrams - diagrams of dispersion, indicate that there is not a single point that is beyond the scope of +3 to -3 , which means that there are no atypical points, which is also one of the conditions for a regression analysis.

Figure 2. Normal Probability Plot of dependent variables

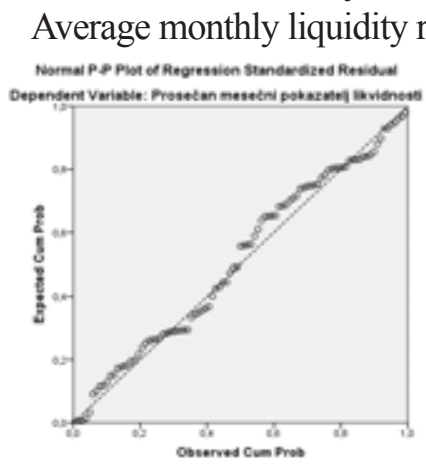

LTD ratio

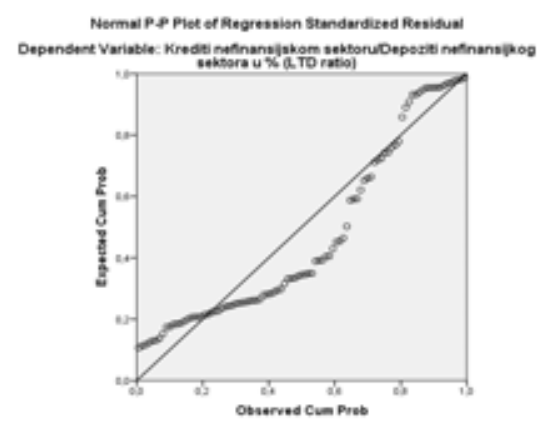

Source: Work of authors 
Figure 3. Scatterplot diagram of dependent variables

Average monthly liquidity ratio

LTD ratio

Scatterplot
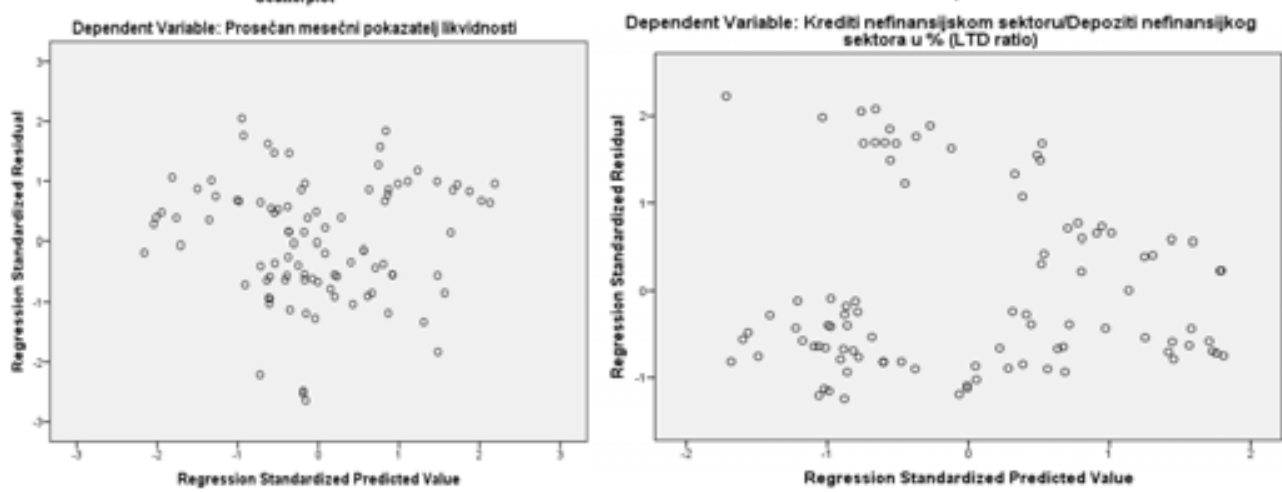

Source: Work of authors

By examining the correlation between the independent variables included in the regression analysis it was found that some parameters significantly correlated with each other (UNIP and the IPC, $\mathrm{p}=0.000$, Pearson coefficient $=0.542 \mathrm{ro}$, ro $=0.544$ ), but given the fact that the Pearson correlation coefficient is not greater than 0.7 it is found that the condition for the absence of multicollinearity is not disturbed and we can continue with further analysis.

Table 3. Correlations

\begin{tabular}{|c|c|c|c|c|c|}
\hline & & averLiq & UNIP & CPI & IIP \\
\hline \multirow{4}{*}{$\begin{array}{l}\text { Pearson } \\
\text { Correlation }\end{array}$} & averLiq & 1.000 & .553 & .090 & -.041 \\
\hline & UNIP & .553 & 1.000 & .544 & -.092 \\
\hline & CPI & .090 & .544 & 1.000 & .063 \\
\hline & IIP & -.041 & -.092 & .063 & 1.000 \\
\hline \multirow{4}{*}{ Sig. (1-tailed) } & averLiq & & ,000 & 191 & ,346 \\
\hline & UNIP & .000 & . &, 000 & , 187 \\
\hline & CPI & .191 & .000 & . & .271 \\
\hline & IIP & .346 & .187 & .271 & . \\
\hline \multirow[t]{4}{*}{$\mathbf{N}$} & averLiq & 96 & 96 & 96 & 95 \\
\hline & UNIP & 96 & 96 & 96 & 95 \\
\hline & CPI & 96 & 96 & 96 & 95 \\
\hline & IIP & 95 & 95 & 95 & 95 \\
\hline
\end{tabular}

Source: Author 
Table 4. Correlations

\begin{tabular}{|c|c|c|c|c|c|}
\hline & & LTD & UNIP & CPI & IIP \\
\hline \multirow{4}{*}{ Pearson Correlation } & LTD & 1.000 & .544 & .563 & .034 \\
\hline & UNIP & .544 & 1.000 & .542 & -.092 \\
\hline & CPI & .563 & .542 & 1.000 & .063 \\
\hline & IIP & .034 & -.092 & .063 & 1.000 \\
\hline \multirow{4}{*}{ Sig. (1-tailed) } & LTD & & .000 & .000 & .371 \\
\hline & UNIP & .000 & & .000 & .187 \\
\hline & CPI & .000 & .000 & & .271 \\
\hline & IIP & .371 & .187 & .271 & . \\
\hline \multirow{4}{*}{$\mathbf{N}$} & LTD & 95 & 95 & 95 & 95 \\
\hline & UNIP & 95 & 95 & 95 & 95 \\
\hline & CPI & 95 & 95 & 95 & 95 \\
\hline & IIP & 95 & 95 & 95 & 95 \\
\hline
\end{tabular}

Source: Author

Another proof of the absence of multicollinearity is represented by the value of Tolerance $(>0: 10$ in all columns) and VIF ( $<10$ also in all the columns) that are displayed in the table below.

Table 5. Coefficients ${ }^{\mathrm{ab}}$

\begin{tabular}{|c|c|c|c|c|c|c|c|}
\hline \multirow{2}{*}{\multicolumn{2}{|c|}{ Model }} & \multicolumn{2}{|c|}{$\begin{array}{c}\text { Collinearity } \\
\text { Statistics }\end{array}$} & \multirow{2}{*}{\multicolumn{2}{|c|}{ Model }} & \multicolumn{2}{|c|}{$\begin{array}{c}\text { Collinearity } \\
\text { Statistics }\end{array}$} \\
\hline & & \multirow[t]{2}{*}{ Tolerance } & \multirow[t]{2}{*}{ VIF } & & & \multirow[t]{2}{*}{ Tolerance } & \multirow[t]{2}{*}{ VIF } \\
\hline \multirow{4}{*}{1} & (Constant) & & & \multirow{4}{*}{2} & (Constant) & & \\
\hline & UNIP & .689 & 1.452 & & UNIP & .690 & 1.449 \\
\hline & CPI & .692 & 1.446 & & CPI & 693 & 1.443 \\
\hline & IIP & .973 & 1.027 & & IIP & .973 & 1.027 \\
\hline
\end{tabular}

a. Dependent Variable: averLiq

b. Dependent Variable: LTD

Source: Author

The table below indicates the intensity of the correlation between the dependent variable - the average monthly liquidity averLiq (as a ratio of liquid assets and liquid liabilities) and independent macroeconomic variables such as unemployment, inflation and index of industrial production. The correlation is calculated from 96 samples for independent variables affecting the dependent variable averLiq. Preliminary analysis has shown that the assumptions of normality, linearity, multicollinearity and homogeneity of variance are not affected. Using Pearson's correlation coefficient, it was observed that there is no connection between all variables. Medium, i.e. weak positive degree of correlation, exists between the average monthly liquidity and the unemployment rate and it can be said that the correlation is statistically significant at the significance level of .001 i.e. medium degree of correlation 
indicates that unemplyment rate explained $30.58 \%$ of the variance of the observed trends of the average monthly liquidity. The index of industrial production shows that there is the negligible correlation with the dependent variable and that it is not statistically significant. Negligible negative correlation without statistical significance refers to the average monthly liquidity and index of industrial production.

Table 6. Correlations

\begin{tabular}{|l|l|r|}
\hline \multicolumn{4}{|c|}{ UNIP } & Pearson Correlation & averLiq \\
\cline { 2 - 3 } & Sig. (2-tailed) & $.553^{* *}$ \\
\cline { 2 - 3 } & $\mathrm{N}$ & .000 \\
\hline \multirow{4}{*}{ CPI } & Pearson Correlation & 96 \\
\cline { 2 - 3 } & Sig. (2-tailed) & .090 \\
\cline { 2 - 3 } & $\mathrm{N}$ & .383 \\
\hline \multirow{3}{*}{ IIP } & Pearson Correlation & 96 \\
\cline { 2 - 3 } & Sig. (2-tailed) & -.041 \\
\cline { 2 - 3 } & $\mathrm{N}$ & .691 \\
\hline
\end{tabular}

**. Correlation is significant at the 0.01 level (2-tailed).

Source: Author

The following table also shows the intensity and direction of the correlation between the dependent variable - loans-to-deposit ratio to non-financial sector (LTD) and independent macroeconomic variables such as unemployment, inflation and industrial production index. The correlation is calculated from 96 samples for independent variables affecting the dependent variable LTD. Using Pearson's correlation coefficient, it was observed that there is no connection between all variables. Medium, i.e. weak positive correlation exists between LTD ratios and the unemployment rate and consumer price index (CPI), so it can be said that the correlation is statistically significant at the significance level of .001 i.e. medium degree of correlation indicates that the variance of observed trend of liquidity indicator is explained $29.59 \%$ by unemployment rate. Also, medium degree of correlation indicates that consumer price index explained $31.81 \%$ of the variance of observed trend of this liquidity indicator. The correlation coefficient for the index of industrial production shows that there is the negligible correlation with the dependent variable and that it is not statistically significant.

Table 7. Correlations

\begin{tabular}{|c|c|c|}
\hline & & LTD \\
\hline \multirow{3}{*}{ UNIP } & Pearson Correlation & $.544^{* *}$ \\
\hline & Sig. (2-tailed) & .000 \\
\hline & $\mathrm{N}$ & 96 \\
\hline \multirow{3}{*}{ CPI } & Pearson Correlation & $.564^{* *}$ \\
\hline & Sig. (2-tailed) & .000 \\
\hline & $\mathrm{N}$ & 96 \\
\hline
\end{tabular}




\begin{tabular}{|c|c|c|}
\hline & & LTD \\
\hline \multirow{3}{*}{ IIP } & Pearson Correlation & .034 \\
\hline & Sig. (2-tailed) & .742 \\
\hline & $\mathrm{N}$ & 95 \\
\hline
\end{tabular}

**. Correlation is significant at the 0.01 level (2-tailed).

Source: Author

Based on the research of three macroeconomic factors of liquidity, it can be concluded that the index of industrial production is not correlated with the dependent variable for both liquidity indicators. For independent variable - inflation, we can say it correlated with the dependent variable LTD, but not with averLiq. Namely, higher inflation reduces the credit activity of banks and causes an increase in the share of most liquid reserves in the balance sheet total. One of the main reasons of resulting interdependence is a fact that a significant rise in consumer prices affects the reduction in aggregate demand, which reduces economic activity and demand for loans (Račić, 2014). There is often a dilemma between inflation and unemployment, in the short term. If economic policies are implemented in the direction of increasing aggregate demand, it will reduce unemployment but it will increase inflation. If, however, the economy opts for decreasing aggregate demand, that can lower inflation, but increasee unemployment, at least temporarily. Namely, when the central bank reduced the money supply growth rate (inflation), it reduces aggregate demand and that reduces the amount of produced goods and services, which leads to an increase in unemployment. To reduce inflation, an economy must endure a period of high unemployment and low production. Independent variable - the unemployment rate, had an impact on both indicators of the dependent variable. The increase in unemployment rate entails a reduction in the creditworthiness of borrowers, and therefore the banks' credit activities. Also, the banking sector increases the share of liquid assets in total assets, thus increasing the liquidity of the banking sector.

After the establishment of the relation (correlation) between the observed variables, the research question was set: how well the unemployment rate, inflation and the index of industrial production (together) may predict liquidity (averLiq) i.e. LTD, and which of these factors is the best averLiq and LTD predictor (what affects the most the change in averLiq and LTD). For this purpose, a multiple regression was used. After verifying that the requirements for the analysis are fulfilled, we evaluated the models and the contribution of each independent variable to the model as a whole.

In the ANOVA Table the value Sig is less than 0.05, which means that in general it is not statistically significant. Specifically, a set of variables (UNIP, CPI and IPP) can predict the value of liquidity indicator averLiq. In the Model Summary Table, R value or Adjusted R-Square of 0.370 (0.349) shows that specified model explaines $35 \%$ of variance averLiq-a. Other percentage of variance can be explained by other variables that are not incorporated in the model (i.e. averLiq indicator of liquidity does not depend only on these three but on some other parameters). 
Table 8. ANOVA $^{\mathrm{a}}$

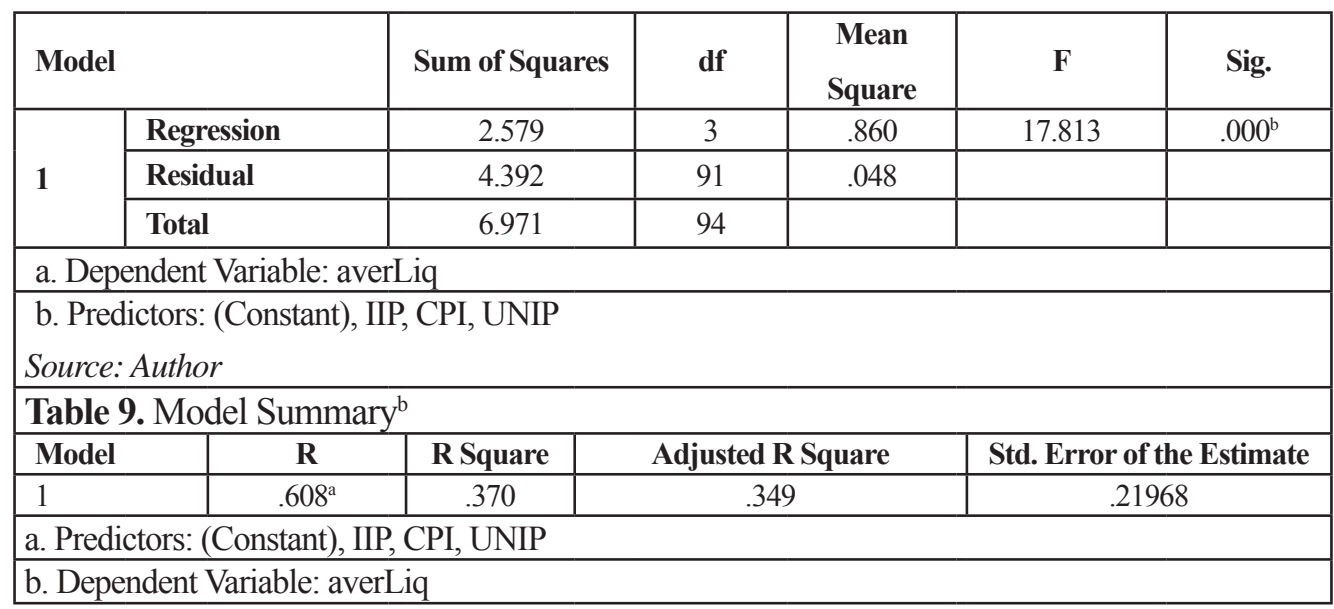

\section{Source: Author}

The following table shows how each independent variable in the model contributes to the prediction of the dependent variable. Thus, UNIP and CPI provide a statistically significant unique contribution to a predictive power of the model, while it is not the case with IIP. In this case, the standardized beta coefficient shows that UNIP with a value of 0.723 has a significantly greater contribution to the assessment of the liquidity ratio averLiq than CPI whose value of the beta coefficient is 0.306 . More specifically, the Beta coefficient indicates only which independent variable better assesses the dependent variable, while the correlation coefficients in the column Part (squared) show what percentage of variance of the dependent variable is explained by which independent variable.

Table 10. The coefficients of a multiple regression analysis ${ }^{\mathrm{a}}$

\begin{tabular}{|c|c|c|c|c|c|c|c|c|c|c|c|c|c|}
\hline \multirow{2}{*}{\multicolumn{2}{|c|}{ Model }} & \multicolumn{2}{|c|}{$\begin{array}{c}\text { Unstandard. } \\
\text { Coeff }\end{array}$} & \multirow{2}{*}{$\begin{array}{c}\begin{array}{c}\text { Standa- } \\
\text { rdized } \\
\text { Coeffici- } \\
\text { ents }\end{array} \\
\text { Beta }\end{array}$} & \multirow{2}{*}{$\mathrm{t}$} & \multirow{2}{*}{ Sig. } & \multicolumn{2}{|c|}{$\begin{array}{c}95,0 \% \text { Conf } \\
\text { Int for B }\end{array}$} & \multicolumn{3}{|c|}{ Correlations } & \multicolumn{2}{|c|}{$\begin{array}{c}\text { Collinearity } \\
\text { Statistics }\end{array}$} \\
\hline & & B & $\begin{array}{l}\text { Std. } \\
\text { Error }\end{array}$ & & & & 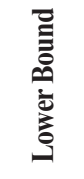 & 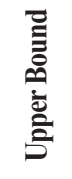 & 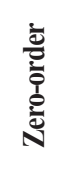 & : & 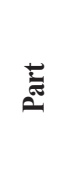 & 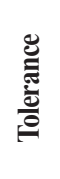 & 告 \\
\hline \multirow{4}{*}{1} & (Constant) & -2.040 & .636 & & -3.206 & .002 & -3.305 & -.776 & & & & & \\
\hline & UNIP & .139 & .019 & .723 & 7.208 & .000 & .101 & .177 & .553 & .603 & .600 & .689 & 1.452 \\
\hline & CPI & -.019 & .006 & -.306 & -3.054 & .003 & -.031 & -.007 & .090 & -.305 & -.254 & .692 & 1.446 \\
\hline & IIP & .001 & .002 & .045 & .530 & .597 & -.003 & .006 & -.041 & .055 & .044 & .973 & 1.027 \\
\hline
\end{tabular}

Source: Author 
The correlation coefficients in the column Part, provide information on which part of the variance of the liquidity ratio averLiq is explained by UNIP, and which part is explained by CPI. The squared value from the table $\left(0.600^{2}=0.36\right)$ means that $36 \%$ of the variance averLiq liquidity can be explained by differences in the unemployment rate. CPI explains only $6 \%$ of the variance of liquidity. From the above it can be concluded that a statistically significant unique contribution to assessing the liquidity is provided by UNIP and the CPI, with larger UNIP contribution than CPI.

The following analysis relating to the evaluation of model 2 which refers to the dependent variable LTD. In the ANOVA Table, it is estimated that the model as a whole is statistically significant. This means that a set of variables (UNIP, CPI, IIP) can predict the value of LTDs, as previous analysis showed for averLiq. In table Model Summary, Adj.R square-value of between 0.379 demonstrates that specifed model explaines $38 \%$ of LTD variance - which is very similar to the previously obtained results for averLiq-a.

In table Coefficients of multiple regression analysis, it can be seen that a statistically significant unique contribution to the predictive power of the model as a whole give two variables: UNIP and CPI $(p=0.001$ and $p=0.000)$. Based on the observed values of standardized beta coefficients, the contribution of these two variables to predictive character of the model in the case of prediction LTD is very similar (0.346 and 0.372), while for the assessment averLiq UNIP had more significant contribution. However, for the prediction of LTD, CPI has slightly higher beta coefficient. Based on Part coefficients, it can be concluded that the CPI can explain $9.6 \%$ of the LTD variance, while UNIP as a single predictor explains $8.2 \%$ of the LTD variance.

Table 11. Model Summary ${ }^{\mathrm{b}}$

\begin{tabular}{|c|c|c|c|c|}
\hline Model & $\mathbf{R}$ & R Square & $\begin{array}{c}\text { Adjusted R } \\
\text { Square }\end{array}$ & $\begin{array}{c}\text { Std. Error of the } \\
\text { Estimate }\end{array}$ \\
\hline $\mathbf{2}$ & $.632^{\mathrm{a}}$ & .399 & .379 & 9.28316 \\
\hline a. Predictors: (Constant), IIP, CPI, UNIP & \multicolumn{3}{|c|}{ b. Dependent Variable: LTD } \\
\hline
\end{tabular}

Source: Author

Table 12. ANOVA $^{\mathrm{a}}$

\begin{tabular}{|l|l|r|r|r|r|r|}
\hline \multicolumn{2}{|l|}{ Model } & $\begin{array}{c}\text { Sum of } \\
\text { Squares }\end{array}$ & df & $\begin{array}{c}\text { Mean } \\
\text { Square }\end{array}$ & F & Sig. \\
\hline \multirow{3}{*}{2} & Regression & 5207.585 & 3 & 1735.862 & 20.143 & $.000^{\mathrm{b}}$ \\
\cline { 2 - 8 } & Residual & 7842.119 & 91 & 86.177 & & \\
\cline { 2 - 7 } & Total & 13049.704 & 94 & & & \\
\hline
\end{tabular}

Source: Author 
Table 13. Coefficients of multiple regression analysis ${ }^{\mathrm{a}}$

\begin{tabular}{|c|c|c|c|c|c|c|c|c|c|c|c|c|c|}
\hline \multirow{2}{*}{\multicolumn{2}{|c|}{ Model }} & \multicolumn{2}{|c|}{$\begin{array}{l}\text { Unstand. } \\
\text { Coefficients }\end{array}$} & \multirow{2}{*}{$\begin{array}{c}\begin{array}{c}\text { Standardized } \\
\text { Coefficients }\end{array} \\
\text { Beta }\end{array}$} & \multirow[b]{2}{*}{ t } & \multirow[b]{2}{*}{ Sig. } & \multicolumn{2}{|c|}{$\begin{array}{c}95,0 \% \\
\text { Confidence } \\
\text { Interval for B }\end{array}$} & \multicolumn{3}{|c|}{ Correlations } & \multicolumn{2}{|c|}{$\begin{array}{c}\text { Collinearity } \\
\text { Statistics }\end{array}$} \\
\hline & & & & & & & 韮 & 恶 & $\dot{\Xi}$ & & & & \\
\hline \multirow{4}{*}{2} & (Constant) & 20.323 & 26.787 & & .759 & .450 & -32.885 & 73.532 & & & & & \\
\hline & UNIP & 2.865 & .810 & .346 & 3.537 & .001 & 1.256 & 4.474 & .544 & .348 & .287 & .690 & 1.449 \\
\hline & CPI & .986 & .258 & .372 & 3.814 & .000 & .472 & 1.499 & .563 & .371 & .310 & .693 & 1.443 \\
\hline & IIP & .052 & .101 & .043 & .518 & .606 & -.148 & .253 & .034 & .054 & .042 & 973 & 1.027 \\
\hline
\end{tabular}

Source: Author

After the obtained research results which show that the banking sector liquidity is under the influence of inflation and unemployment rates, the next reasionable step is to analyse their aforementioned impact on agricultural development. Thus, due to the high unemployment rate, the number of potential borrowers as well as the ability of current borrowers to repay a loan are reduced. This situation leads to an increase in liquid assets of the bank. Under the influence of high inflation, the reduced demand for bank loans occurs, which again increases the liquidity of banks.

Given the fact that the banking sector is one of the financiers of agricultural production, its level of liquidity, i.e. level of credit activity is of paramount importance. Loans approved to the agricultural sector by the banking sector, are characterized by a series of adverse circumstances. Due to the seasonal nature of agricultural work, the influx of them also has seasonal character. Such dynamics of movement of resources does not suit banks because they expect a monthly payment of liabilities arising from loans. In this way, the bank can monitor the financial condition of the client. Otherwise, the bank would be exposed to greater risks and would charged a higher interest rate on that basis (Lukic, 2012). Due to the high unpredictability of agricultural production caused by climate changes, farmers represent a high risk to the banking sector. In case of bad weather conditions, producers have a smaller amount of products, product prices rise, and banks prescribe additional collateral to protect themselves.

Farmers have the poorest access to financial resources from all sectors in Serbia (Veselinović, 2014). Therefore, agricultural entities in the Republic of Serbia should be offered with adequate agricultural credit. This agricultural credit should be approved without a currency clause and adapted to the seasonal nature of agricultural production and financial capabilities of agricultural subjects. Finally, this agricultural credit should be modeled on the concept of favorable farmer loan from the financing system of agriculture in the United States. (Radović, 2015). With the arrival of foreign banks, the ratio of agricultural loans to total loans increased. In order to further increase the previously mentioned share of agricultural loans, it is necessary to ensure the longer 
deadlines for financing in dinars, facilitate the sale of agricultural products in dinars, as well as in euros.

The following table shows the movements of loans to agricultural sector in relation to the liquidity ratios. The increasing trend of liquidity ratios may be noted in the periods when there was a fall in the share of agricultural loans compared to total loans (except in 2008).

Table 14. Macroprudential indicators in the period from 2008 to 2015

\begin{tabular}{|l|c|c|c|c|c|c|c|c|}
\hline & $\mathbf{2 0 0 8 .}$ & $\mathbf{2 0 0 9}$ & $\mathbf{2 0 1 0 .}$ & $\mathbf{2 0 1 1 .}$ & $\mathbf{2 0 1 2 .}$ & $\mathbf{2 0 1 3 .}$ & $\mathbf{2 0 1 4 .}$ & $\mathbf{2 0 1 5 .}$ \\
\hline $\begin{array}{l}\text { Agricultural loans } \\
\text { in relation to total } \\
\text { loans }\end{array}$ & 3.3 & 3.1 & 3.0 & 2.8 & 3.0 & 2.7 & 3.5 & 3.7 \\
\hline $\begin{array}{l}\text { Liquid assets in } \\
\text { relation to short } \\
\text { term liabilities } \\
\text { (averliq) }\end{array}$ & 68.6 & 63.6 & 56.4 & 62.8 & 57.5 & 62.2 & 56.3 & 52.0 \\
\hline $\begin{array}{l}\text { Loans to deposits } \\
\text { ratios to non } \\
\text { financial sector } \\
\text { (LTD) }\end{array}$ & 125.3 & 124.8 & 125.9 & 127.0 & 119.9 & 113.8 & 102.7 & 99.0 \\
\hline
\end{tabular}

Source: National bank of Serbia

Bearing in mind the aforementioned facts, the banking sector should take advantage of the period when there is a favorable influence of macro economic factors (decline in the unemployment and inflation) on the banking sector liquidity and in that way. incite bigger credit investment into the agriculture sector.

Bank loans as a form of financing the agricultural sector also provide liquidity and continuity of agricultural production. After the global economic crisis, which was strongly felt by the domestic banking sector, banks in Serbia have more problems with the so-called nonperforming loans (NPLs). According to the National Bank of Serbia, in the third quarter of 2016 and in the observed industries, processing industry continues to have the largest share in the total NPLs of companies (a share of 38\%, with the nonperforming loans to total gross loans indicator of $21.6 \%$ ), trade (share of $25 \%$, with the nonperforming loans to total gross loans indicator of $15.9 \%$ ) and construction (share of $15 \%$, with the nonperforming loans to total gross loans indicator of $32.5 \%$ ). The share of agriculture in total nonperforming loans is small and amounts to $2 \%$, or about 4 billion, which may indicate that farmers are neat payers. Exactly these data should be the motive of the banking sector to finance agriculture. This would fulfill both the expectations of the banking sector for increased business performance and the aim of the agricultural sector for higher level of production driven by more adequate financial support.

\section{Conclusion}

The study results speak in favor of the fact that selected macroeconomic factors defined the liquidity of the banking sector to the medium extent. UNIP, CPI and IIP affect in a very similar 
way the averLiq and LTD, because the overall predictive power of both regression models is very similar (35 and 38\%) and because both parameters affect the UNIP and the CPI, while IIP does not correlate with these parameters or give a statistically significant unique contribution to a predictive power regression models neither for averLiq not LTD. In addition, UNIP is more significant predictor than CPI, while for prediction of LTD, UNIP and CPI are almost equally significant, with a slight advantage of CPI. Based on the aforementioned, we can conclude that it is necessary to implement appropriate economic measures, which would set the rate of unemployment and inflation within the limits of permitted framework. The banking sector would then, without major obstacles and difficulties, manage to regulate liquidity at the optimum level and enable the bigger share of agricultural loans and thus stimulate agricultural development. Motivating the banking system to start financing agricultural sector is viable if the condition of the banking sector liquidity is met, if the share of agriculture in the total NPLs is reduced and if the requirements of political and macroeconomic stability are fulfilled.

The research could be useful for commercial banks so they can look at the quality of its business performance operations and look for ways to maintain them in those segments which have proven to be good, or improve them in those segments which deviate from the desired value and thus imrove conditions for funding real agriculture sector. Only in that case, banks will be able to fulfill their commitment to running a successful business in relation to real agriculture sector in a serious, scientifically based and practically confirmed way. Future research on this topic will open new chapter of research depending on the availability of the database itself. Considering a longer time interval, and including not only the macroeconomic factors but also microeconomic and subjective factors, will help further research to provide more reliable and more practically applicable results.

\section{Bibliography}

1. Alihodžić, A. (2015): Međusobna uslovljenost performansi bankarskog i realnog sektora Republike Srbije, Bankarstvo 2, UDK 336.71:338.1(497.11)'2008/2014", Udruženje banaka Srbije, Beograd, Srbija.

2. Basel Committee on Banking Supervision (2000): Sound Practices for Managing Liquidity on Banking Organisations, Basel, Switzerland, (Available at: http://www.bis. org/publ/bcbs69.pdf)

3. Cvetinović, M. (2008): Upravljanje rizicima u finansijskom poslovanju, Univerzitet Singidunum, Beograd., Srbija.

4. Ćirović, M. (2008): Bankarstvo, Bridge Company, Beograd, Srbija.

5. Jurman, A., (2004): Rizik likvidnosti u poslovnoj banci, Zbornik Pravnog fakulteta Sveučilišta u Rijeci, Vol. 25, no. 2, Rijeka, Hrvatska.

6. Klincov, R., Majstorović, A., Miloradić, J. (2017): Vrednovanje rizika u finansijskom menadžmentu, Oditor, Belgrade, Serbia, Vol. 3, No. 1, pp. 114-125.

7. Lukić, S., Cvetković, S. (2012): Razvojne banke kao oslonac u kreditiranju poljoprivrede, Civitas - časopis za društvena istraživanja, Fakultet za pravne i poslovne studije dr Lazar 
Vrkatić, UDK 336.77/.78:631, Novi Sad, Srbija.

8. Narodna banka Srbije (2010): Godišnji izveštaj o poslovanju i rezultatima rada u 2010. godini, (Available at: http://www.nbs.rs/export/sites/default/internet/latinica/90/90_4/ godisnji_izvestaj_2010.pdf)

9. Narodna banka Srbije (2016): Izveštaj o inflaciji-Februar 2016. godine.

(Available at: http://www.nbs.rs/export/download/pdf_ioi/ioi_02_2016.pdf)

10. Narodna banka Srbije (2015).:Godišnji izveštaj o poslovanju i rezultatima rada u 2015. godini, (Available at:http://www.nbs.rs/export/sites/default/internet/latinica/90/90_4/ godisnji_izvestaj_2015.pdf)

11. Narodna Banka Srbije, (2016): Bankarski sektor u Srbiji, Izveštaj za III tromesečje 2016. godine, (Available at: https:/www.nbs.rs/internet/latinica/55/55_4/kvartalni izvestaj_III_16.pdf)

12. Narodna banka Srbije (2015): Statistički bilten,.(Available at:http:/www.nbs.rs/static/ nbs_site/gen/latinica/90/statisticki/sb_12_15.pdf)

13. Narodna banka Srbije (2011): Odluka o upravljanju rizicima, (Available at:http://www. nbs.rs/export/sites/default/internet/latinica/20/kpb/upravljanje_rizicima.pdf)

14. Narodna banka Srbije (2016): Tromesečni pregled kretanja indikatora finansijske stabilnosti Republike Srbije, (Available at http://www.nbs.rs/internet/latinica/18/ pregled_grafikona.pdf)

15. Radović, G. (2015): Finansiranje poljoprivrede u Republici Srbiji: iskustva imogućnosti, Ekonomija - teorija i praksa, godina VIII, broj 4, Novi Sad, Srbija . (Available at: http:// scindeks-clanci.ceon.rs/data/pdf/2217-5458/2015/2217-54581504013R.pdf)

16. Račić, Ž. (2014): Uticaj osnovnih makroekonomskih pokazatelja na likvidnost bankarskog sektora Srbije, Škola biznisa, broj 2/2014, UDC 336.71(497.11), DOI 10.5937/skolbiz2-6916, Novi Sad, Srbija.

17. Official gazette of the RS, 129/2007., Odluka o upravljanju rizikom likvidnosti banke, Srbija.

18. Saunders, A. (2000): Financial Institutions Management, The McGraw-Hill/ Irwin Series in Finance, Insurance, and Real Estate Irwin, New York, (Available at: http://www.bulentsenver.com/FIN5477/Financial_Institutions_Management AntonySaunders_TextBook.pdf)

19. Trenca, I., Petria, N., Mutu, S., Corovei, E. (2012): Evaluating the liquidity determinats in the central and eastern European banking system, Finance-Challenges of the Future, Year XII, No.14/2012, 85-90, Faculty of Economics and Business Administration, Univeristy of Craiova, (Available at: http://feaa.ucv.ro/FPV/014-11.pdf)

20. Treći poljoprivredni forum, Hrana za Evropu, Investirajno u agroprivredu Srbije, Subotica, 17-19. October 2013. godine

21. Van, G. Bratanović-Brajlović S. (2003): Analyzing and Managing Banking Risk - A Framework for Assesing Corporate Governance and Financial Risk, The World 
Bank, Washington D.C., USA, (Available at: http://documents.worldbank.org/curated/ en/310191468350113153/pdf/multi0page.pdf)

22. Uprava za agrarna plaćanja, Ministarstvo poljoprivrede i zaštite životne sredine, Strategija poljoprivrede i ruralnog razvoja Republike Srbije za period 2014-2024. godine ("Official gazette of the RS" no. 85/2014) (Available at: http://uap.gov.rs/wpcontent/uploads/2016/05/STRATEGIJA-2014-2020-.pdf )

23. Vodová, P. (2013): Determinants which affect liquid assets ratio of Czech and Slovak commercial banks. Financial Assets and Investing, No. 1/2013, DOI: 10.5817/FAI2013$1-2$

24. Vodová, P. (2011): Determinants of Commercial Bank’s Liquidity in Slovakia, Czech Science Foundation. (Project GACR P403/11/P243). (Available at: http://www.opf.slu. cz/kfi/icfb/proc2011/pdf/65_vodova.pdf)

25. Veselinović, B., Drobnjaković M. (2014): Qualitative and quantitative analysis of micro and macro aspects of agricultural finance, Economics of agriculture, Vol 61,No 3,771-787, Naučno društvo agrarnih ekonomista Balkana, Beograd. Srbija. (Available.at:http://ageconsearch.umn.edu/bitstream/186525/2/15\%20EP\%203\%20 2014.pdf)

26. Zakić, V., Kljajić, N. (2016): Analiza stanja finansijske pismenosti poljoprivrednih proizvođača $i$ modeli finansiranja poljoprivredne proizvodnje u Republici Srbiji, Unapređenje finansijskih znanja i evidencije na poljoprivrednim gazdinstvima $u$ Republici Srbiji, Institut za ekonomiku poljoprivrede Beograd, Beograd, Srbija. 


\title{
ANALIZA MAKROEKONOMSKIH DETERMINANTI LIKVIDNOSTI \\ BANKARSKOG SEKTORA U FUNKCIJI FINANSIRANJA POLJOPRIVREDNOG SEKTORA
}

\author{
Dragana Milič̉, Dragan Soleša ${ }^{4}$
}

\begin{abstract}
Rezime
Istraživanjem u ovom radu, nastojalo se identifikovati koji su to faktori od najvećeg uticaja na likvidnost bankarskog sektora zarad podrške poljoprivrednom sektoru. Cilj istraživanja se zasniva na oceni da li i na koji način varijacije makroekonomskih faktora utiču na izloženost bankarskog sektora riziku likvidnosti, što određuje spremnost bankarskog sektora da odgovori na rastuće finansijske potrebe poljoprivrede. Primenom adekvatnih statističkih metoda poput korelacije i višsestruke regresione analize, dobijaju se signifikantni rezultati koji mogu biti osnova za praćenje i merenje ne/likvidnosti bankarskog sektora u odnosu na sektor realne poljoprivrede. Dobijeni rezultati potvrđuju značaj inflacije i stope nezaposlenosti kao odrednice likvidnosti bankarskog sektora, što omogućuje planiranje tj. predviđanje izdvojenih sredstava za poljoprivredni sektor.
\end{abstract}

Ključne reči: Makroekonomski faktori, likvidnost bankarskog sektora, statističke metode, poljoprivredni razvoj.

3 Dragana Milić, Asistent, Visoka poslovna škola strukovnih studija, Ulica Vladimira Perića Valtera br. 4, 21000 Novi Sad, Srbija, Telefon: +381 214854 000, E-mail: draganaim84@gmail.com

4 Redovni professor, dr Soleša Dragan, Univerzitet Privredna akademija, Fakultet za ekonomiju i inženjerski menadžment, Cvećarska ulica br. 2, 21000 Novi Sad, Telefon: +381 21400 484, E-mail: solesadragan@gmail.com 